\title{
Evaluation of Paranasal Sinus Anatomic Variations and Mucosal Changes with Cone Beam Computed Tomography
}

\begin{abstract}
SUMMARY
Background/Aim: Anatomical variations of paranasal sinuses are common and play an role in disrupting the drainage of the sinuses, which often causes chronic sinusitis. In this article, anatomical variations of the paranasal sinuses and its relationship with mucosal changes were evaluated retrospectively by cone beam computed tomography (CBCT) which is also known as dental volumetric tomography. Material and Methods: CBCT data of 500 patients who applied to Cukurova University Faculties of Dentistry for any reason were retrospectively evaluated by maxillofacial radiologist. Anatomical variants of paranasal sinuses were included in the study. Mucosal thickening greater than $2 \mathrm{~mm}$ in the maxillary sinus was considered pathological. Results: The most common anatomic variation in the study was the nasal septal deviation, found in 302 (60.4\%) patients. The least common anatomic variation in the study was lower concha pneumatization found in $3(0.6 \%)$ patients. Mucosal thickening of the maxillary sinus was observed in 271 (54.2\%) cases in the right sinus and 260 (52\%) cases in the left sinus $(p>0.05)$. Conclusions: Nasal septum deviation was the most common variation in the study. According to the results of our study, concha bullosa, haller cell and the uncinate process had no definite effect on mucosal thickening in the maxillary sinus.
\end{abstract}

Key words: $\mathrm{CBCT}$, Paranasal Sinuses, Mucosal Changes, Anatomical Variations

\author{
Katibe Tuğçe Temur ${ }^{1}$, Burcu Evlice2, \\ Haluk Öztunç3 \\ ${ }^{1}$ Department of Oral and Maxillofacial \\ Radiology, Faculty of Dentistry, Niğde Omer \\ Halisdemir University, Niğde, Turkey \\ ${ }^{2}$ Department of Oral and Maxillofacial \\ Radiology, Faculty of Dentistry, Cukurova \\ University, Adana, Turkey \\ ${ }^{3}$ Department of Oral and Maxillofacial \\ Radiology, Faculty of Dentistry, University of \\ Kyrenia, Kyrenia, Turkish Republic of Northern \\ Cyprus
}

\author{
ORIGINAL PAPER (OP)
}

Balk J Dent Med, 2022;27-32

\section{Introduction}

The maxillary, ethmoid, sphenoid and frontal sinuses form the paranasal sinuses. These sinuses contain air and are connected to the nasal cavity through ostiums ${ }^{1}$. The last common way of drainage and aeration of frontal, maxillary and anterior ethmoid air cells is called an osteomeatal complex. Concha bullosa, haller cell and agger nasi cells are anatomical variations of the osteomeatal complex ${ }^{2}$. Anatomical variations of this region are common and play an important role in disrupting the drainage of the sinuses, which often causes chronic sinusitis ${ }^{3}$. On the other hand, anatomical variations must be evaluated correctly in the successful and safe implementation of functional sinus surgery ${ }^{4}$. In chronic diseases of this region, preoperative imaging methods are used. Computerized Tomography
(CT) is considered the gold standard for the display of this region ${ }^{5}$. CT provides detailed visualization of the nasal cavity, lateral nasal wall, osteomeatal complex and sinuses prior to functional endoscopic sinus surgery ${ }^{6}$. However, the disadvantage is that the cost and radiation doses of CT application are high. For these reasons, CBCT application is an ideal method of dentistry for dentistry. Besides that, the exact role of CBCT in the otolaryngology area is still uncertain. $\mathrm{CBCT}$ eliminates some of the disadvantages of $\mathrm{CT}$, in this respect it is superior ${ }^{5,7}$.

In studies conducted on this region in the literature, it was observed that $\mathrm{CT}$ was used as an imaging method and use of CBCT is limited. In this article, anatomical variations of the paranasal sinuses and its relationship with mucosal changes were evaluated retrospectively by CBCT which is also known as dental volumetric tomography. 


\section{Material and Methods}

It was planned to retrospectively evaluate $\mathrm{CBCT}$ data of 500 patients who applied to Çukurova University Faculties of Dentistry for any reason between November 2014 and May 2016. Our study was approved by Çukurova University Medical Faculty Non-Interventional Clinical Research Ethics Committee as decision No. 20.

\section{Criteria of images included in the study}

Patients who did not suffer from trauma or accident in his head and neck within the image area of the paranasal sinuses, without systemic or genetic disease, without congenital disease such as cleft lip and palate, and who did not undergo surgical operation in the areas to be examined were included in the study.

CBCT data were excluded from the study when the desired regions were not within the image area, images with patient or device-related errors during the shooting, and artefacts formed in the image due to metallic filling or crown bridge prostheses that made evaluation impossible.

\section{Technical specifications and images assessment conditions of $C B C T$ device}

CBCT images were obtained with dental volumetric imaging system (Planmeca ProMax 3D Mid, FACE module) operating at $90 \mathrm{kV}$ and $8 \mathrm{~mA}$. Image analyzes were performed using a software (Planmeca Romexis Version 4.4.0.R, Planmeca Oy, Helsinki, Finland).

\section{Evaluated regions and evaluation criteria}

Nasal septal deviation, concha bullosa, haller cell, uncinate process pneumatisation, nasal septal pneumatization, paradoxical middle turbinate, lower concha hypertrophy, lower concha pneumatization, crista galli pneumatisation, maxillary sinus pneumatization, maxillary sinus septa, maxillary sinus hypoplasia, maxillary sinus exostosis as paranasal sinus anatomical variants were included in the study (Figures 1-5). Anatomical variations were evaluated using axial, coronal and sagittal sections as variation or no variation. In anatomic variations that can be seen bilaterally, both sides were evaluated separately. Mucosal thickening greater than $2 \mathrm{~mm}$ in the maxillary sinus was considered pathological (Figure 6). In addition, the effect of anatomical variations (concha bullosa, uncinate process pneumatisation and haller cell) located close to the middle meatus of the paranasal sinuses and possibly causing narrowing of the osteomeatal complex and therefore thought to cause mucosal changes in the maxillary sinuses, on the mucosal thickening in the maxillary sinuses were investigated.

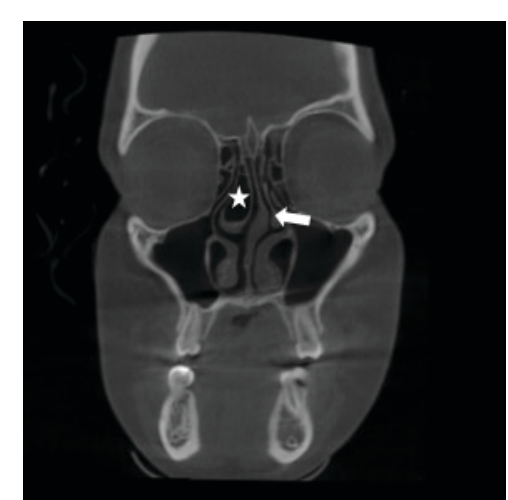

Figure 1. Asterisk: Concha bullosa Arrow: Nasal septal deviation

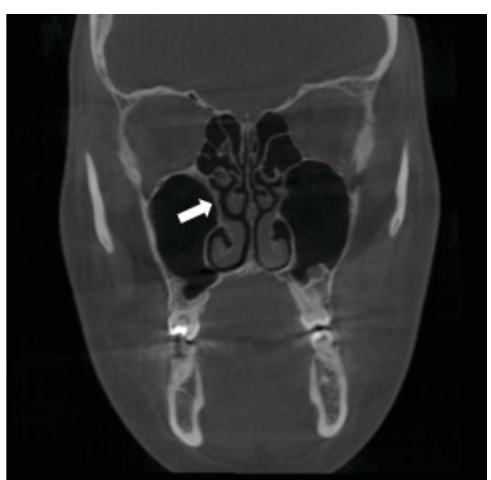

Figure 3. Arrow: Paradoxıcal middle turbınate pneumatization

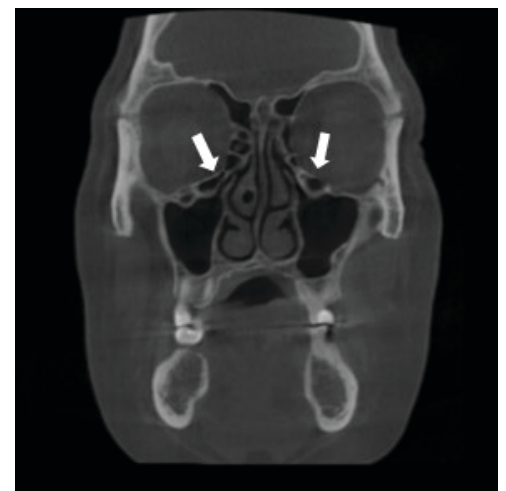

Figure 2. Arrow: Haller Cell

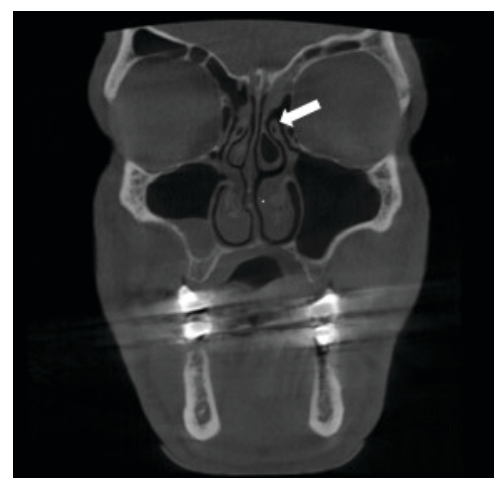

Figure 4. Arrow: Uncinate process 


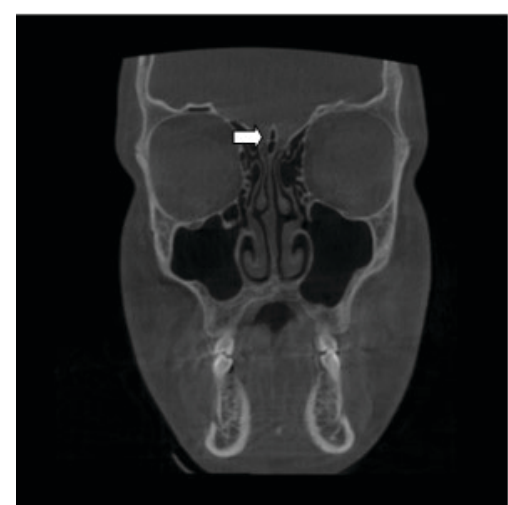

Figure 5. Arrow: Crista galli pneumatization

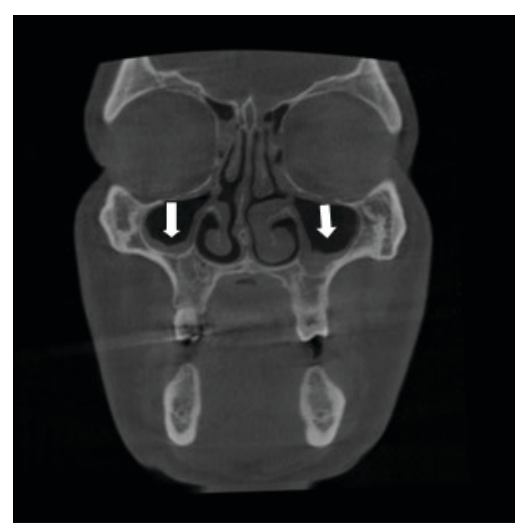

Figure 6. Coronal cross-section of the mucosal thickening of the right and left maxilla $C B C T$

Special evaluation forms were prepared for this study. It was evaluated by an oral maxillofacial radiologist.

\section{Data analysis}

The data obtained from the study were transferred to the computer in the SPSS 23.0 package program and analyzed. Continuous variables were presented as mean \pm standard deviation, and frequency data were presented as number (\%). Chi-square test was used to compare the data obtained, and the statistical significance level of these tests was considered as $\mathrm{p}<0.05$.

\section{Results}

In this study, paranasal sinus anatomic variations of 500 patients were examined (51\% males and $49 \%$ females). The age of all patients was between 18 and 81 and the average was 39.7 ( \pm 16.178$)$. No significant relationship was found between age and gender and anatomical variations. $(p>0.05)$
In the study, the frequency of paranasal sinus anatomical variation is given in the Table 1. Mucosal thickening of the maxillary sinus was observed in 271 $(54.2 \%)$ cases in the right sinus and $260(52 \%)$ cases in the left sinus (Table 2). No significant correlation was found between the presence of uncinate pneumatization, haller cell and concha bullosa and mucosal thickening in the maxillary sinus $(\mathrm{p}>0.05)$.

Table 1. Anatomical variation prevalence

\begin{tabular}{|c|c|c|}
\hline ANATOMICAL VARIATIONS & NUMBER & PERCENT \\
\hline NASAL SEPTAL DEVIATION & 302 & 60.4 \\
\hline CONCHA BULLOSA RIGHT & 159 & 31.8 \\
\hline CONCHA BULLOSA LEFT & 169 & 33.8 \\
\hline CONCHA BULLOSA BILATERAL & 116 & 23.2 \\
\hline HALLER CELL RIGHT & 87 & 17.4 \\
\hline HALLER CELL LEFT & 90 & 18.0 \\
\hline $\begin{array}{l}\text { LOWER CONCHA } \\
\text { HYPERTROPHY RIGHT }\end{array}$ & 150 & 30 \\
\hline $\begin{array}{l}\text { LOWER CONCHA } \\
\text { HYPERTROPHY LEFT }\end{array}$ & 118 & 23.6 \\
\hline $\begin{array}{l}\text { PARADOXICAL MIDDLE } \\
\text { TURBINATE RIGHT }\end{array}$ & 42 & 8.4 \\
\hline $\begin{array}{l}\text { PARADOXICAL MIDDLE } \\
\text { TURBINATE LEFT }\end{array}$ & 44 & 8.8 \\
\hline $\begin{array}{l}\text { NASAL SEPTAL } \\
\text { PNEUMATIZATION }\end{array}$ & 30 & 6.0 \\
\hline $\begin{array}{l}\text { UNCINATE PROCESS } \\
\text { PNEUMATIZATION RIGHT }\end{array}$ & 47 & 9.4 \\
\hline $\begin{array}{l}\text { UNCINATE PROCESS } \\
\text { PNEUMATIZATION LEFT }\end{array}$ & 47 & 9.4 \\
\hline $\begin{array}{l}\text { LOWER CONCHA } \\
\text { PNEUMATIZATION }\end{array}$ & 3 & 0.6 \\
\hline $\begin{array}{l}\text { CRISTA GALLI } \\
\text { PNEUMATIZATION }\end{array}$ & 7 & 1.4 \\
\hline $\begin{array}{l}\text { MAXILLARY SINUS } \\
\text { PNEUMATIZATION RIGHT }\end{array}$ & 145 & 29 \\
\hline $\begin{array}{l}\text { MAXILLARY SINUS } \\
\text { PNEUMATIZATION LEFT }\end{array}$ & 159 & 31.8 \\
\hline $\begin{array}{l}\text { MAXILLARY SINUS SEPTA } \\
\text { RIGHT }\end{array}$ & 222 & 44.4 \\
\hline MAXILLARY SINUS SEPTA LEFT & 236 & 47.2 \\
\hline $\begin{array}{l}\text { MAXILLARY SINUS } \\
\text { HYPOPLASIA RIGHT }\end{array}$ & 11 & 2.2 \\
\hline $\begin{array}{l}\text { MAXILLARY SINUS } \\
\text { HYPOPLASIA LEFT }\end{array}$ & 4 & 0.8 \\
\hline $\begin{array}{l}\text { MAXILLARY SINUS EXOSTOSIS } \\
\text { RIGHT }\end{array}$ & 5 & 1 \\
\hline $\begin{array}{l}\text { MAXILLARY SINUS EXOSTOSIS } \\
\text { LEFT }\end{array}$ & 7 & 1.4 \\
\hline
\end{tabular}




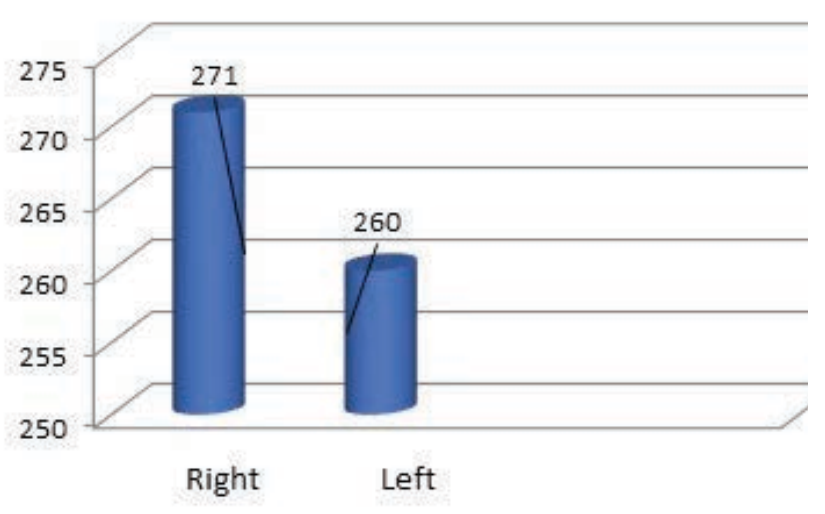

Table 2. Prevalence of maxillary sinus mucosal thickening

\section{Discussion}

Paranasal anatomical variations may play a role in the etiology of chronic rhinosinusitis (CRS), but this issue is still unclear ${ }^{8}$. Nasal septum deviation is the most common variation in the population in our study $(60.4 \%)$. The prevalence of this variation, determined in some studies, was reported to be $19.4 \%{ }^{9}, 65 \%{ }^{10}$, and $59.5 \%{ }^{11}$. If nasal septum deviation is in contact with hypertrophic concha or concha bullosa and narrows the middle meatus, this can cause infection of all sinuses by disrupting normal mucus drainage ${ }^{11}$.

Concha bullosa is the pneumatisation of the middle turbinate ${ }^{12}$. In our study, the rate of right concha bullosa was $31.8 \%$, the rate of left concha bullosa was $33.8 \%$, and bilateral turbinate ratio was $23.2 \%$. When the literature was examined, the prevalence of concha bullosa in children and adults was reported to be $34.1 \%{ }^{13}$, $44 \%{ }^{10}$ and $51 \%{ }^{14}$. However, the effect of concha bullosa on sinus infection is controversial. In a study, it was reported that concha bullosa is highly associated with sinus pathologies ${ }^{15}$. Nevertheless, in many studies, no relationship between concha bullosa and sinus pathologies was found ${ }^{16}$.

Infraorbital ethmoidal air cells are called Haller cells ${ }^{17}$. In the studies in the literature, the prevalence of the haller cell is $27.3 \%^{2} 7.8 \%{ }^{11}$. In our study, the rate of haller cell right was $17.4 \%$ and the rate of haller cell left was $18 \%$.

In our study, the rate of lower turbinate pneumatization and hypertrophy was lower than some studies in the literature 18,19 . The ratio of paradoxical middle turbinate right was $8.4 \%$ and the ratio of paradoxical middle turbinate left was $8.8 \%$. In the literature, the prevalence of paradoxical middle turbinate varies between $11.6^{2}$ and $30 \%{ }^{20}$. The rate of nasal septal pneumatisation was $6 \%$. Nasal septal pneumatisation prevalence in previous studies was reported as $6 \%{ }^{21}$ and $2 \%{ }^{10}$.
In our study, the rate of uncinate prosess pneumatisation right and left was 9.4\%. Uncinate prosess pneumatisation prevalence in literature was reported to be $2 \%^{21}, 5 \%^{22}$, and $13.8 \%{ }^{11}$. It was reported that uncinate process may cause functional blockage in the osteomeatal complex, and that the large contact formed by the middle concha of a prominently medially bent or pneumatized process is the most common pathological finding in patients with sinusitis in their populations $^{22}$.

Crista galli is normally bony. When ventilated, it can connect with the anterior recess, causing obstruction of the ostium, thereby leading to chronic sinusitis and mucocele formation. Another rare anatomical variation in our study findings was crista galli pneumatisation at rate of $1.4 \%$. In literature, the prevalence of this variation was reported to be $2.4 \%^{23}, 3.3 \%{ }^{11}$.

In our study, it can be said that the incidence of septa from maxillary sinus variations is close to the study of Park et al. using three-dimensional imaging $\operatorname{method}^{24}$. The incidence of maxillary pneumatization, hypoplasia and exocytosis is lower than the studies in the literature ${ }^{25-28}$.

In the literature, in the studies conducted mostly with $\mathrm{CT}$, there is a difference in the rates of anatomical variations in the paranasal sinus. We think that difference in prevalences of anatomic variations may be due to the reasons for performing these studies, made in different populations, different classifications of anatomical variations, and changes in the image quality of the different imaging devices used.

There is no consensus in the literature on the amount of mucosal thickening considered pathological. However, mucosal thickenings of $2 \mathrm{~mm}$ or more than 5 $\mathrm{mm}$ are considered abnormal ${ }^{29,30}$. We included mucosal thickening of $2 \mathrm{~mm}$ and above to be abnormal, and found the right mucosal thickening rate as $54.2 \%$ and the left mucosal thickening rate as $52 \%$. In the literature, the prevalence of mucosal thickening of the maxillary sinus ranged from $12 \%{ }^{31}$ to $60.5 \%{ }^{30}$. We did not find that the presence of uncinate process pneumatization, haller cell and concha bullosa affect mucosal thickening in the maxillary sinus ( $\mathrm{p}>0.05)$.

\section{Conclusions}

Nasal septum deviation was the most common variation in the study. Concha bullosa, haller cell and the uncinate process pneumatization had no definite effect on mucosal thickening in the maxillary sinus. CBCT designed for the maxillofacial region and being applicable for both before functional sinus surgery or endoscopic examination 
of otolaryngologists and before implant surgery of dentists can be preferred in the evaluation of the paranasal sinuses and their anatomical variations, due to their advantages such as the image detail and low radiation dose.

\section{References:}

1. Al-Abri R, Bhargava D, Al-Bassam W, Al-Badaai Y, Sawhney SJOmj. Clinically significant anatomical variants of the paranasal sinuses. Oman Med J, 2014;29:110.

2. Bandyopadhyay R, Biswas R, Bhattacherjee S, Pandit N, Ghosh S. Osteomeatal Complex: A Study of Its Anatomical Variation Among Patients Attending North Bengal Medical College and Hospital. Indian J Otolaryngol Head Neck Surg, 2015;67:281-286.

3. Calhoun KH, Waggenspack GA, Simpson CB, Hokanson JA, Bailey BJ. CT Evaluation of the Paranasal Sinuses in Symptomatic and Asymptomatic Populations. Otolaryngol Head and Neck Surg, 1991;104:480-483.

4. Nouraei SAR, Elisay AR, DiMarco A, Abdi R, Majidi H, Madani SA, Andrews PJ. Variations in paranasal sinus anatomy: implications for the pathophysiology of chronic rhinosinusitis and safety of endoscopic sinus surgery. J Otolaryngology Head Neck Surg, 2009;38:32-37.

5. Guldner C, Ningo A, Voigt J, Diogo I, Heinrichs J, Weber R, Wilhelm T, Fibeich M. Potential of dosage reduction in cone-beam-computed tomography (CBCT) for radiological diagnostics of the paranasal sinuses. Eur Arch Otorhinolaryngol, 2013; 270:1307-1305.

6. Weber ALJR. History of head and neck radiology: past, present, and future. Radiology, 2001;218:15-24.

7. Shokri A, Miresmaeili A, Farhadian N, Falah-Kooshki S, Amini P, Mollaie N. Effect of changing the head position on accuracy of transverse measurements of the maxillofacial region made on cone beam computed tomography and conventional posterior-anterior cephalograms. Dentomaxillofac Radiol, 2017;46:20160180.

8. Azila A, Irfan M, Rohaizan Y, Shamim AJTMJoM. The prevalence of anatomical variations in osteomeatal unit in patients with chronic rhinosinusitis. Med J Malaysia, 2011;66:191-194.

9. Smith KD, Edwards PC, Saini TS, Norton NS. The prevalence of concha bullosa and nasal septal deviation and their relationship to maxillary sinusitis by volumetric tomography. Int J Dent, 2010;2010:404982.

10. Stallman JS, Lobo JN, Som PMJ The incidence of concha bullosa and its relationship to nasal septal deviation and paranasal sinus disease. AJNR Am J Neuroradiol, 2004;25:1613-1618.

11. Dasar U, Gokce E. Evaluation of variations in sinonasal region with computed tomography. World J Radiol, 2016;8:98-108.

12. Stammberger HR, Kennedy DW, Paranasal sinuses: anatomic terminology and nomenclature. Ann Otol Rhinol Laryngol, 1995;104:7-16.
13. Nitinavakarn B, Thanaviratananich S, Sangsilp N. Anatomical variations of the lateral nasal wall and paranasal sinuses: A CT study for endoscopic sinus surgery (ESS) in Thai patients. J Med Assoc Thai, 2005;88:763-768.

14. Al-Qudah M. The relationship between anatomical variations of the sino-nasal region and chronic sinusitis extension in children. Int $\mathrm{J}$ Pediatr Otorhinolaryngol, 2008;72:817-821.

15. Lloyd GA. CT of the paranasal sinuses: study of a control series in relation to endoscopic sinus surgery. J Laryngol Otol, 1990;104:477-481.

16. Aktas D, Kalcioglu MT, Kutlu R, Ozturan O, Oncel S. The relationship between the concha bullosa, nasal septal deviation and sinusitis. Rhinology, 2003;41:103-106.

17. Reddy UD, Dev B. Pictorial essay: Anatomical variations of paranasal sinuses on multidetector computed tomography-How does it help FESS surgeons? Indian J Radiol Imaging, 2012;22:317.

18. Özcan C, Görür K, Nass Duce M. Imagining case study of the month: Massive bilateral inferior concha bullosa. Ann Otol Rhinol Laryngol, 2002;111:100-101.

19. Çakur B, Sümbüllü MA, Yılmaz AB. Relationship among hypertrophy of inferior turbinate, deviation of nasal septum and antral retention cyst. J Dent Fac Atatürk Uni, 2011;21:5-9.

20. Bolger WE, Butzin CA, Parsons DS. Paranasal sinus bony anatomic variations and mucosal abnormalities: CT analysis for endoscopic sinus surgery. Laryngoscop, 1991;101:56-64.

21. Sivasli E, Sirikci A, Bayazit YA, Gumusburun E, Erbagci $\mathrm{H}$, Bayram M, et al. Anatomic variations of the paranasal sinus area in pediatric patients with chronic sinusitis. Surg Radiol Anat, 2002;24:399-404.

22. Kantarci M, Karasen RM, Alper F, Onbas O, Okur A, Karaman A. Remarkable anatomic variations in paranasal sinus region and their clinical importance. Eur J Radiol, 2004;50:296-302.

23. Basic N, Basic V, Jukic T, Basic M, Jelic M, Hat J. Computed tomographic imaging to determine the frequency of anatomical variations in pneumatization of the ethmoid bone. Eur Arch Otolaryngol, 1999;256:69-71.

24. Park IH, Song JS, Choi H, Kim TH, Hoon S, Lee SH, Lee HM. Volumetric study in the development of paranasal sinuses by CT imaging in Asian: a Pilot study. Int J Pediatr Otorhinolaryngol, 2010;74:1347-1350.

25. Bozdemir E, Gormez O, Yıldırım D, Aydogmus Erik A. Paranasal sinus pathoses on cone beam computed tomography. J Istanb Univ Fac Dent, 2016;50:27-34.

26. Sirikçi A, Bayazit Y, Gümüsburun E, Bayram M, Kanlikana M. A new approach to the classification of maxillary sinus hypoplasia with relevant clinical implications. Surg Radiol Anat, 2000;22:243-247.

27. Alkurt MT, Peker I, Demirel O, Akay G, Gungor K, Ucok $\mathrm{O}$. The prevalence of antral exostoses in the maxillary sinuses, evaluated by cone-beam computed tomography. J Dent Sci, 2016;11:225-230.

28. Lana JP, Carneiro PM, Machado Vde C, de Souza PE, Manzi FR, Horta MC. Anatomic variations and lesions of the maxillary sinus detected in cone beam computed tomography for dental implants. Clin Oral Implants Res, 2012;23:1398-1403. 
29. Tarp B, Fiirgaard B, Christensen T, Jensen JJ, Black FT. The prevalence and significance of incidental paranasal sinus abnormalities on MRI. Rhinology, 2000;38:33-38.

30. Shanbhag S, Karnik P, Shirke P, Shanbhag V. Association between Periapical Lesions and Maxillary Sinus Mucosal Thickening: A Retrospective Cone-beam Computed Tomographic Study. J Endod, 2013;39:853-857.

31. Vallo J, Suominen-Taipale L, Huumonen S, Soikkonen K, Norblad A. Prevalence of mucosal abnormalities of the maxillary sinus and their relationship to dental disease in panoramic radiography: results from the Health 2000 Health Examination Survey. Oral Surg Oral Med Oral Pathol Oral Radiol Endod, 2010;109:80-87.

Conflict of Interests: Nothing to declare.

Financial Disclosure Statement: This study was supported by Çukurova University Research Funds project No. TDH20166199.
Human Rights Statement: All the procedures on humans were conducted in accordance with the Helsinki Declaration of 1975, as revised 2000. Consent was obtained from the patient/s and approved for the current study by national ethical committee.

Animal Rights Statement: None required.

Received on September 8, 2020.

Revised on November 28, 2020.

Accepted on Jun 20, 2021.

Correspondence:

Katibe Tuğçe Temur

Department of Oral and Maxillofacial Radiology

Faculty of Dentistry, Niğde Omer Halisdemir University

Niğde, Turkey

e-mail: tugcetemur@ohu.edu.tr 